\title{
Front Matter: Volume 7789
}

, "Front Matter: Volume 7789," Proc. SPIE 7789, Laser Beam Shaping XI, 778901 (8 September 2010); doi: 10.1117/12.877002

SPIE Event: SPIE Optical Engineering + Applications, 2010, San Diego, California, United States 


\section{PROCEEDINGS OF SPIE}

\section{Laser Beam Shaping XI}

Andrew Forbes

Todd E. Lizotte

Editors

2 August 2010

San Diego, California, United States

Sponsored and Published by

SPIE

Volume 7789

Proceedings of SPIE, 0277-786X, v. 7789 
The papers included in this volume were part of the technical conference cited on the cover and title page. Papers were selected and subject to review by the editors and conference program committee. Some conference presentations may not be available for publication. The papers published in these proceedings reflect the work and thoughts of the authors and are published herein as submitted. The publisher is not responsible for the validity of the information or for any outcomes resulting from reliance thereon.

Please use the following format to cite material from this book:

Author(s), "Title of Paper," in Laser Beam Shaping XI, edited by Andrew Forbes, Todd E. Lizotte, Proceedings of SPIE Vol. 7789 (SPIE, Bellingham, WA, 2010) Article CID Number.

ISSN 0277-786X

ISBN 9780819482853

Published by

SPIE

P.O. Box 10, Bellingham, Washington 98227-0010 USA

Telephone +1 3606763290 (Pacific Time) · Fax +1 3606471445

SPIE.org

\section{Copyright () 2010, Society of Photo-Optical Instrumentation Engineers}

Copying of material in this book for internal or personal use, or for the internal or personal use of specific clients, beyond the fair use provisions granted by the U.S. Copyright Law is authorized by SPIE subject to payment of copying fees. The Transactional Reporting Service base fee for this volume is $\$ 18.00$ per article (or portion thereof), which should be paid directly to the Copyright Clearance Center (CCC), 222 Rosewood Drive, Danvers, MA 01923. Payment may also be made electronically through CCC Online at copyright.com. Other copying for republication, resale, advertising or promotion, or any form of systematic or multiple reproduction of any material in this book is prohibited except with permission in writing from the publisher. The CCC fee code is 0277-786X/10/\$18.00.

Printed in the United States of America.

Publication of record for individual papers is online in the SPIE Digital Library.

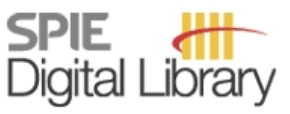

SPIEDigitalLibrary.org

Paper Numbering: Proceedings of SPIE follow an e-First publication model, with papers published first online and then in print and on CD-ROM. Papers are published as they are submitted and meet publication criteria. A unique, consistent, permanent citation identifier (CID) number is assigned to each article at the time of the first publication. Utilization of CIDs allows articles to be fully citable as soon they are published online, and connects the same identifier to all online, print, and electronic versions of the publication. SPIE uses a six-digit CID article numbering system in which:

- The first four digits correspond to the SPIE volume number.

- The last two digits indicate publication order within the volume using a Base 36 numbering system employing both numerals and letters. These two-number sets start with $00,01,02,03,04$, $05,06,07,08,09,0 A, 0 B \ldots 0 Z$, followed by 10-1Z, 20-2Z, etc.

The CID number appears on each page of the manuscript. The complete citation is used on the first page, and an abbreviated version on subsequent pages. Numbers in the index correspond to the last two digits of the six-digit CID number. 


\section{Contents}

vii Conference Committee
ix Introduction

SESSION 1 METHODS I

778902 Axicons, prisms and integrators: searching for simple laser beam shaping solutions [7789-01] T. Lizotte, Hitachi Via Mechanics (USA), Inc. (United States)

778903 Computer-generated hologram statistics [7789-02]

C. López-Mariscal, Instituto Tecnológico y de Estudios Superiores de Monterrey (Mexico)

778904 Wavelength-independent laser beam shaping [7789-03]

M. P. Degama, Council for Scientific and Industrial Research (South Africa) and Univ. of KwaZulu-Natal (South Africa); A. Forbes, Council for Scientific and Industrial Research (South Africa), Univ. of KwaZulu-Natal (South Africa), and Stellenbosch Univ. (South Africa)

778905 Phase computer generated holograms to encode structured light fields: a numerical and experimental evaluation [7789-04]

R. Carrada, V. Arrizón, U. Ruiz, Instituto Nacional de Astrofísica, Óptica y Electrónica (Mexico)

778906 Performance improvements of binary diffractive structures via optimization of the photolithography and dry etch processes [7789-05]

K. Welch, J. Leonard, R. D. Jones, Tessera (United States)

778907 Applying refractive beam shapers to improve other beam shaping techniques [7789-06] A. Laskin, Molecular Technology GmbH (Germany); G. Williams, The Univ. of Sheffield (United Kingdom); R. McWilliam, Durham Univ. (United Kingdom); V. Laskin, Molecular Technology GmbH (Germany)

\section{SESSION 2 METHODS II}

778908 Optical aberrations in gas lenses [7789-07]

C. Mafusire, Council for Scientific and Industrial Research (South Africa) and Univ. of KwaZulu-Natal (South Africa); A. Forbes, Council for Scientific and Industrial Research (South Africa), Univ. of KwaZulu-Natal (South Africa), and Stellenbosch Univ. (South Africa); M. M. Michaelis, Univ. of KwaZulu-Natal (South Africa); G. Snedden, Council for Scientific and Industrial Research (South Africa)

778909 Acousto-optical delay lines for femtosecond pulse shaping based on crystal materials with strong acoustic anisotropy [7789-08]

V. Y. Molchanov, S. I. Chizhikov, National Univ. of Science and Technology (Russian Federation); O. Y. Makarov, Molecular Technology GmbH (Germany); E. A. Khazanov, V. N. Ginzburg, Institute of Applied Physics (Russian Federation) 
7789 OA Laser beam homogenization, splitting and three spot image formation: system design, analysis and testing [7789-09]

T. Lizotte, Hitachi Via Mechanics (USA), Inc. (United States); F. Dickey, FMD Consulting LLC (United States); D. Brown, Optosensors Technology, Inc. (United States)

7789 OB Deformable mirrors for laser beam shaping [7789-10]

V. Samarkin, A. Kudryashov, Moscow State Open Univ. (Russian Federation)

\section{SESSION 3 NON-DIFFRACTING AND VORTEX BEAMS}

7789 OC Higher-order Bessel like beams with z-dependent cone angles [7789-11]

$Y$. Ismail, Council for Scientific and Industrial Research (South Africa) and Univ. of KwaZulu-Natal (South Africa); G. Barnes, T. Mhlanga, Univ. of KwaZulu-Natal (South Africa); V. Belyi, B.I. Stepanov Institute of Physics (Belarus); A. Forbes, Council for Scientific and Industrial Research (South Africa) and Univ. of KwaZulu-Natal (South Africa)

7789 OD Overall shaping of light beams by means of spiral phase elements [7789-12] R. Martínez-Herrero, P. M. Mejías, Univ. Complutense de Madrid (Spain); A. Manjavacas, Consejo Superior de Investigaciones Científicas (Spain)

$7789 \mathrm{OF}$ Controlling orbital angular momentum using forked polarization gratings [7789-14] Y. Li, J. Kim, M. J. Escuti, North Carolina State Univ. (United States)

\section{SESSION 4 APPLICATIONS}

$7789 \mathrm{OH}$ Challenges of UV light processing of low UVT foods and beverages (Invited Paper) [7789-16] T. Koutchma, Agriculture and Agri-Food Canada (Canada)

7789 Ol UV-laser-based longitudinal illuminated diffuser (LID) incorporating diffractive and Lambertian reflectance for the disinfection of beverages [7789-17]

T. Lizotte, Pivotal Development Co., LLC (United States)

$77890 \mathrm{~J}$ The potential for optical beam shaping of UV laser sources for mass scale quarantine disinfection applications [7789-18]

T. Lizotte, Pivotal Development Co., LLC (United States)

7789 OK Beam shaping optical system and optical system of laser printer [7789-19]

M. Onishi, J. Rauseo, D. Seki, K. Hatade, Nalux Co., Ltd. (Japan)

7789 OL Quantum cascade laser integrated with metal-dielectric-metal plasmonic antenna [7789-20]

D. Dey, R. M. Gelfand, J. Kohoutek, A. Bonakdar, H. Mohseni, Northwestern Univ. (United States)

$7789 \mathrm{OM}$ Ablation of silicon by focusing a femtosecond laser through a subwavelength annular aperture structure [7789-21]

Y. Y. YU, National Taiwan Univ. (Taiwan); C. K. Chang, M. W. Lai, Industrial Technology Research Institute (Taiwan); L. S. Huang, National Taiwan Univ. (Taiwan); C. K. Lee, National Taiwan Univ. (Taiwan) and Industrial Technology Research Institute (Taiwan) 
778900 Capillary bundle design for laser beam shaping in laser leveling devices [7789-23]

J. Y. Jhang, G.-D. J. Su, National Taiwan Univ. (Taiwan)

7789 OP Spatial filter with volume gratings for high-peak-power multistage laser amplifiers [7789-24]

Y. Tan, Y. Yang, G. Zheng, B. Shen, H. Pan, L. Liu, National Univ. of Defense Technology (China)

7789 OQ Propagation characteristics of Cartesian Parabolic-Gaussian beams [7789-25]

D. Lopez-Mago, Instituto Tecnológico y de Estudios Superiores de Monterrey (Mexico); M. A. Bandres, California Institute of Technology (United States); J. C. Gutiérrez-Vega, Instituto Tecnológico y de Estudios Superiores de Monterrey (Mexico)

7789 OT Pulse shaping properties of multilayer reflection volume holographic gratings under an ultrashort pulsed beam with arbitrary temporal shapes [7789-28]

L. Guo, Shandong Univ. of Technology (China); A. Yan, Shanghai Institute of Optics and Fine Mechanics (China)

7789 OV Adaptive feedback beam shaping of the $\mathrm{CO}_{2}$ welding laser [7789-30]

P. Jedlička, Institute of Scientific Instruments of the ASCR, v.v.i. (Czech Republic); L. Mrña, Dendera a.s. (Czech Republic); M. Šarbort, Š. Řeřucha, Institute of Scientific Instruments of the ASCR, v.v.i. (Czech Republic) and Masaryk Univ., Brno (Czech Republic)

7789 OW Shaping a Bessel optical lattice for soliton propagation [7789-31]

A. Ruelas, S. López-Aguayo, J. C. Gutiérrez-Vega, Instituto Tecnológico y de Estudios Superiores de Monterrey (Mexico)

7789 0X Fabrication and characterization of long period fiber gratings with an alternative electric arc method to be applied as optical fiber sensors [7789-32]

R. I. Mata-Chávez, J. M. Estudillo-Ayala, R. Rojas-Laguna, E. Vargas-Rodríguez,

M. Trejo-Duran, E. Alvarado-Méndez, J. A. Andrade-Lucio, Univ. de Guanajuato (Mexico)

7789 OY A computational fluid dynamics model of the spinning pipe gas lens [7789-33]

C. Mafusire, Council for Scientific and Industrial Research (South Africa) and Univ. of KwaZulu-Natal (South Africa); A. Forbes, Council for Scientific and Industrial Research (South Africa), Univ. of KwaZulu-Natal (South Africa), and Stellenbosch Univ. (South Africa); G. Snedden, Council for Scientific and Industrial Research (South Africa)

$77890 Z$ Efficient beam combining with high brightness of a phase-locked laser array [7789-34] A. Yan, L. Liu, E. Dai, J. Sun, Y. Zhou, Y. Zhi, Shanghai Institute of Optics and Fine Mechanics (China)

778910 Evolution of low-frequency noise passing through spatial filter in high power laser system [7789-35]

P. Sun, D. Liu, Y. Zhang, X. Li, Y. Zhang, J. Zhu, Shanghai Institute of Optics and Fine Mechanics (China) 
778911 Design and performance analysis of a tunable and self-pulsation diode pumped double-clad D-shaped Yb $^{3+}$-doped silica fiber laser [7789-36]

A. F. El-Sherif, M. K. El-Tahlawy, Egyptian Armed Forces (Egypt)

778912 Multi-dither algorithm on Shack-Hartmann wavefront sensor for laser beam formation [7789-37]

J. Sheldakova, A. Kudryashov, V. Samarkin, A. Rukosuev, A. Alexandrov, P. Romanov, Moscow State Open Univ. (Russian Federation)

Author Index 


\title{
Conference Committee
}

\author{
Program Track Chair
}

R. John Koshel, Photon Engineering LLC (United States) and College of Optical Sciences, The University of Arizona (United States)

\section{Conference Chairs}

Andrew Forbes, CSIR National Laser Centre (South Africa), University of KwaZulu-Natal (South Africa), and Stellenbosch University (South Africa)

Todd E. Lizotte, Hitachi Via Mechanics (USA), Inc. (United States)

\section{Program Committee}

Daniel M. Brown, Optosensors Technology, Inc. (United States)

Thomas Caughey, INRAD, Inc. (United States)

Fred M. Dickey, FMD Consulting LLC (United States)

Michael Duparré, Friedrich-Schiller-Universität Jena (Germany)

Julio C. Gutiérrez-Vega, Photonics and Mathematical Optics Group (Mexico) and Instituto Tecnológico y de Estudios Superiores de Monterrey (Mexico)

John A. Hoffnagle, IBM Almaden Research Center (United States)

Kurt J. Kanzler, MEMS Optical, Inc. (United States)

Alexis V. Kudryashov, Moscow State Open University (Russian Federation)

William P. Latham, Air Force Research Laboratory (United States)

Carlos López-Mariscal, Photonics and Mathematical Optics Group (Mexico) and Instituto Tecnológico y de Estudios Superiores de Monterrey (Mexico)

Günter Luepke, The College of William \& Mary (United States)

Olivier Magnin, C2 Diagnostics (France)

Paul F. Michaloski, Corning Tropel Corporation (United States)

John Rauseo, Nalux Nano-Optical, Inc. (United States)

José Sasián, College of Optical Sciences, The University of Arizona (United States)

David L. Shealy, The University of Alabama at Birmingham (United States)

Kenneth J. Weible, SUSS MicroOptics SA (Switzerland)

Uwe D. Zeitner, Fraunhofer-Institut für Angewandte Optik und Feinmechanik (Germany)

Shuyan Zhang, The College of William \& Mary (United States) 


\section{Session Chairs}

1 Methods I

Andrew Forbes, CSIR National Laser Centre (South Africa) and University of KwaZulu-Natal (South Africa), and Stellenbosch University (South Africa)

2 Methods II

Andrew Forbes, CSIR National Laser Centre (South Africa) and University of KwaZulu-Natal (South Africa), and Stellenbosch University (South Africa)

3 Non-diffracting and Vortex Beams

Carlos López-Mariscal, Photonics and Mathematical Optics Group (Mexico) and Instituto Tecnológico y de Estudios Superiores de Monterrey (Mexico)

$4 \quad$ Applications

Todd E. Lizotte, Hitachi Via Mechanics (USA), Inc. (United States) 


\section{Introduction}

Laser Beam Shaping XI was very successful, with 32 papers presented. During the start of the conference, I was reflecting on the economic outlook and talking to the people in attendance. Henry Ford once stated, "Why should I clutter my mind with general information when I have people around me who can supply any knowledge I need?" Henry Ford made that comment on the idea of team work within the context of knowledge. I thought the quote was a good illustration of why people should attend conferences. Laser Beam Shaping provides that type of forum; a place to meet and be surrounded by people with shared interests in gaining knowledge on the different aspects of laser beam shaping.

As laser beam shaping moves forward we need to be cognizant that technology needs to be applied to thrive. The life blood of any industry is to aggressively and successfully innovate through applications development in specific markets. We look forward to the Laser Beam Shaping XII conference and hope to once again see new market applications emerge for laser beam shaping technology.

\section{Andrew Forbes Todd E. Lizotte}


Downloaded From: https://www.spiedigitallibrary.org/conference-proceedings-of-spie on 26 Apr 2023

Terms of Use: https://www.spiedigitallibrary.org/terms-of-use 